\title{
PPAR $\alpha$ Regulates Cholinergic-Driven Activity of Midbrain Dopamine Neurons via a Novel Mechanism Involving $\alpha 7$ Nicotinic Acetylcholine Receptors
}

\author{
Miriam Melis, ${ }^{1,2}$ Simona Scheggi, ${ }^{3}$ Gianfranca Carta, ${ }^{1}$ Camilla Madeddu, ${ }^{1}$ Salvatore Lecca, ${ }^{1}$ Antonio Luchicchi, ${ }^{1}$ \\ Francesca Cadeddu, ${ }^{1}$ Roberto Frau, ${ }^{1}$ Liana Fattore, ${ }^{2}$ Paola Fadda, ${ }^{1}$ M. Grazia Ennas, ${ }^{1}$ M. Paola Castelli, ${ }^{1}$ Walter Fratta, ${ }^{1}$ \\ Bjorn Schilstrom, ${ }^{4}$ Sebastiano Banni, ${ }^{1}$ M. Graziella De Montis, ${ }^{3}$ and Marco Pistis ${ }^{1,2}$ \\ ${ }^{1}$ Department of Biomedical Sciences, University of Cagliari, Cittadella Universitaria di Monserrato, 09042 Monserrato, Italy, ${ }^{2} \mathrm{Neuroscience}$ \\ Institute-Cagliari, Consiglio Nazionale delle Ricerche, Cittadella di Monserrato, 09042 Monserrato, Italy, ${ }^{3}$ Department of Molecular and Developmental \\ Medicine, University of Siena, 53100 Siena, Italy, and ${ }^{4}$ Department of Physiology and Pharmacology, Karolinska Institutet, SE-17177 Stockholm, Sweden
}

Ventral tegmental area dopamine neurons control reward-driven learning, and their dysregulation can lead to psychiatric disorders. Tonic and phasic activity of these dopaminergic neurons depends on cholinergic tone and activation of nicotinic acetylcholine receptors (nAChRs), particularly those containing the $\beta 2$ subunit $\left(\beta 2^{\star}\right.$-nAChRs). Nuclear peroxisome proliferator-activated receptors type- $\alpha$ $(\operatorname{PPAR} \alpha)$ tonically regulate $\beta 2^{\star}-\mathrm{nAChRs}$ and thereby control dopamine neuron firing activity. However, it is unknown how and when PPAR $\alpha$ endogenous ligands are synthesized by dopamine cells. Using ex vivo and in vivo electrophysiological techniques combined with biochemical and behavioral analysis, we show that activation of $\alpha 7$-nAChRs increases in the rat VTA both the tyrosine phosphorylation of the $\beta 2$ subunit of $\mathrm{nAChRs}$ and the levels of two $\operatorname{PPAR} \alpha$ endogenous ligands in a $\mathrm{Ca}^{2+}$-dependent manner. Accordingly, in vivo production of endogenous PPAR $\alpha$ ligands, triggered by $\alpha 7-n A C h R$ activation, blocks in rats nicotine-induced increased firing activity of dopamine neurons and displays antidepressant-like properties. These data demonstrate that endogenous PPAR $\alpha$ ligands are effectors of $\alpha 7$-nAChRs and that their neuromodulatory properties depend on phosphorylation of $\beta 2^{\star}$-nAChRs on VTA dopamine cells. This reveals an autoinhibitory mechanism aimed at reducing dopamine cell overexcitation engaged during hypercholinergic drive. Our results unveil important physiological functions of $\mathrm{nAChR} / \mathrm{PPAR} \alpha$ signaling in dopamine neurons and how behavioral output can change after modifications of this signaling pathway. Overall, the present study suggests $\operatorname{PPAR} \alpha$ as new therapeutic targets for disorders associated with unbalanced dopamine-acetylcholine systems.

\section{Introduction}

Ventral tegmental area (VTA) dopamine neurons form the mesocorticolimbic pathway (Albanese and Minciacchi, 1983). They play a role in processing emotionally salient information (Lapish et al., 2007; Mark et al., 2011; Wang and Tsien, 2011) by changing their firing pattern and activity (Wightman and Robinson, 2002). The VTA dopamine cell firing pattern is controlled by extrinsic afferents, among which cholinergic inputs from laterodorsal tegmental nucleus play a critical role (Lodge and Grace, 2006)

\footnotetext{
Received Oct. 1, 2012; revised Feb. 15, 2013; accepted Feb. 21, 2013

Author contributions: M.M., M.G.E., M.P.C., W.F., B.S., S.B., M.G.D.M., and M.P. designed research; M.M., S.S., G.C., C.M., S.L., A.L., F.C., R.F., L.F., and B.S. performed research; M.M., S.S., S.L., R.F., L.F., P.F., M.G.E., M.P.C., S.B., and M.G.D.M. analyzed data; M.M. wrote the paper.

This work was supported by the "Regione Autonoma della Sardegna, Assessorato alla Programmazione": grants for basic research (Legge Regionale 7/2007 to W.F.), through the program "Bursaries for Young Researchers" (Legge Regionale 7/2007 to S.L. and A.L.), and through the program "Visiting Professor" (to B.S.). This research was also supported by the Italian Ministry of University (Grant PRIN 2009: 200928EEX4 to M.P.) and "Fondazione Banco di Sardegna." We thank William T. Dunn III for proofreading this manuscript.

The authors declare no competing financial interests.

Correspondence should be addressed to Dr. Miriam Melis, Department of Biomedical Sciences, University of Cagliari, Cittadella Universitaria, 09042 Monserrato (CA), Italy. E-mail: myriam@unica.it.

DOI:10.1523/JNEUROSCI.4647-12.2013

Copyright $\odot 2013$ the authors $\quad 0270-6474 / 13 / 336203-09 \$ 15.00 / 0$
}

through activation of nicotinic acetylcholine receptors (nAChRs) (Schilström et al., 2003; Mameli-Engvall et al., 2006). Two major forms of $n A C h R s$ are expressed on dopamine cell somata (Yang et al., 2009): high-affinity $\beta 2^{\star}$-nAChRs and low-affinity $\alpha 7$ nAChRs (Clarke et al., 1985; Séguéla et al., 1993; Klink et al., 2001; Wooltorton et al., 2003). Whereas $\beta 2^{\star}$-nAChRs on VTA dopamine cells are required for their transition from tonic to phasic activity (Mameli-Engvall et al., 2006) and for nicotine's reinforcing properties (Picciotto et al., 1998), the functional relevance of somatodendritic $\alpha 7$-nAChRs remains elusive.

We have previously shown that $\beta 2^{\star}$-nAChRs on VTA dopamine cells are bidirectionally regulated by peroxisome proliferatoractivated receptors type- $\alpha(\operatorname{PPAR} \alpha)($ Melis et al., 2010). In fact, $\beta 2^{*}$-nAChRs are required for PPAR $\alpha$ to decrease both dopamine cell activity and VTA net output in vitro, as well as nicotineinduced increased locomotion in vivo. Accordingly, nicotine's effects on the dopamine system are suppressed by synthetic PPAR $\alpha$ agonists (Melis et al., 2008; Mascia et al., 2011; Panlilio et al., 2012). An interaction between $\operatorname{PPAR} \alpha$ and $\beta 2^{\star}$-nAChRs in VTA dopamine cells was then postulated, informed by evidence of PPAR $\alpha$ as modulators of VTA dopamine neuronal activity through activation of tyrosine kinases and phosphatases (Melis et 
al., 2008, 2010). Thus, given that $\beta 2^{\star}$-nAChRs switch dopamine cells from a resting to an excited state (Mameli-Engvall et al., 2006), PPAR $\alpha$ ligands, by negatively modulating $\beta 2^{\star}$-nAChRs, contribute to endogenous mechanisms controlling VTA dopamine cell excitability (Melis et al., 2010). Particularly, the role of endogenous $\operatorname{PPAR} \alpha$ ligands was revealed after increased cholinergic drive through $\mathrm{nAChRs,} \mathrm{suggestive} \mathrm{of} \mathrm{a} \mathrm{reciprocal} \mathrm{control}$ between acetylcholine and PPAR $\alpha$ (Melis et al., 2010).

Endocannabinoid-related $N$-acylethanolamines (NAEs), such as the anorectic oleoylethanolamide (OEA) (Rodríguez de Fonseca et al., 2001; Fu et al., 2003) and the anti-inflammatory palmitoylethanolamide (PEA) (Lo Verme et al., 2005), are endogenous $\operatorname{PPAR} \alpha$ ligands. These lipids are signaling molecules involved in the regulation of diverse physiologic functions (Pistis and Melis, 2010). The mechanisms accounting for PPAR $\alpha$ ligand synthesis in dopamine neurons are unknown, whereas it has been shown that NAE key synthesizing enzymes are $\mathrm{Ca}^{2+}$-dependent (Astarita et al., 2008), and NAE formation in cortical neurons requires enhanced cholinergic tone (Stella and Piomelli, 2001). Therefore, we hypothesized that low-affinity $\mathrm{Ca}^{2+}$-permeable $\alpha 7$-nAChRs (Bertrand et al., 1993) could participate in the regulation of NAE levels in dopamine cells after enhanced cholinergic tone. To test this hypothesis, we investigated the role of $\alpha 7$ $n A C h R s$ in regulating endogenous PPAR $\alpha$ ligand levels, and the resulting modulation of dopamine neuron activity, by using a multidisciplinary approach that involved biochemical and electrophysiological techniques, as well as behavioral analysis.

\section{Materials and Methods}

All procedures were performed in accordance with the Guidelines for the Care and Use of Mammals in Neuroscience and Behavioral Research (National Research Council, 2004) and EEC Council Directives (219/1990 and 220/1990). We made all efforts to minimize pain and suffering and to reduce the number of animals used. Animals were housed in groups of three to six in standard conditions of temperature $\left(21 \pm 1^{\circ} \mathrm{C}\right)$ and humidity $(60 \%)$ under a $12 \mathrm{~h}$ light/dark cycle (lights on at 7:00 A.M.) with food and water available ad libitum.

\section{Electrophysiological studies}

Ex vivo. Whole-cell patch-clamp recordings from Sprague Dawley rat VTA dopamine cells were similar to those described previously (Melis et al., 2008). Briefly, male rats (14-21 d; Harlan) were anesthetized with halothane and killed. A block of tissue containing the midbrain was rapidly dissected and sliced in the horizontal plane $(300 \mu \mathrm{m})$ with a vibratome (VT1000S; Leica) in an ice-cold, low- $\mathrm{Ca}^{2+}$ solution containing (in mM) $126 \mathrm{NaCl}, 1.6 \mathrm{KCl}, 1.2 \mathrm{NaH}_{2} \mathrm{PO}_{4}, 1.2 \mathrm{MgCl}_{2}, 0.625 \mathrm{CaCl}_{2}, 18$ $\mathrm{NaHCO}_{3}$, and 11 glucose. Slices were transferred to a holding chamber with artificial $\mathrm{CSF}\left(\mathrm{ACSF} ; 37^{\circ} \mathrm{C}\right)$ saturated with $95 \% \mathrm{O}_{2}$ and $5 \% \mathrm{CO}_{2}$ containing (in mM) $126 \mathrm{NaCl}, 1.6 \mathrm{KCl}, 1.2 \mathrm{NaH}_{2} \mathrm{PO}_{4}, 1.2 \mathrm{MgCl}_{2}, 2.4$ $\mathrm{CaCl}_{2}, 18 \mathrm{NaHCO}_{3}$, and 11 glucose. Slices (two per animal) were allowed to recover for at least $1 \mathrm{~h}$ before being placed (as hemislices) in the recording chamber and superfused with the $\operatorname{ACSF}\left(37^{\circ} \mathrm{C}\right)$ saturated with $95 \% \mathrm{O}_{2}$ and $5 \% \mathrm{CO}_{2}$. Cells were visualized with an upright microscope with infrared illumination (Axioskop FS 2 plus; Zeiss), and whole-cell current-clamp recordings (one per hemislice) were made by using an Axopatch 200B amplifier (Molecular Devices). Current-clamp experiments were made with electrodes filled with a solution containing the following (in mM): $144 \mathrm{KCl}, 10$ HEPES, 3.45 BAPTA, $1 \mathrm{CaCl}_{2}, 2.5$ $\mathrm{Mg}_{2} \mathrm{ATP}$, and $0.25 \mathrm{Mg}_{2} \mathrm{GTP}$ (pH 7.2-7.4, 275-285 mOsm). Biocytin $(0.2 \%)$ was added to the internal solution to mark the recorded neuron for later cytochemical characterization. However, as reported previously by Zhang et al. (2010), recording from neurons with this intracellular solution for longer than 3 min impairs immunocytochemical detection of tyrosine hydroxylase (TH). Therefore, we performed a set of experiments with a K-gluconate internal solution because all recorded neurons strongly express $\mathrm{TH}$ immunocytochemical signal regardless of recording duration (Margolis et al., 2010). The K-gluconate internal solution contained the following (in $\mathrm{mM}$ ): $133.5 \mathrm{~K}$-gluconate, $1.8 \mathrm{NaCl}, 10 \mathrm{HEPES}$, 0.05 EGTA, $1.7 \mathrm{MgCl}_{2}, 2 \mathrm{Mg}_{2} \mathrm{ATP}$, and $0.4 \mathrm{Mg}_{2} \mathrm{GTP}$ ( $\mathrm{pH}$ 7.2-7.4, 275$285 \mathrm{mOsm}$ ). All experiments were begun only after series resistance had stabilized (typically $15-40 \mathrm{M} \Omega$ ). Data were filtered at $2 \mathrm{kHz}$, digitized at $10 \mathrm{kHz}$, and collected on-line with acquisition software (pClamp 8.2; Molecular Devices). Dopamine neurons were identified according to the already published criteria (Melis et al., 2007, 2008): cell morphology and anatomical location (i.e., medial to the medial terminal nucleus of the accessory optic tract), large hyperpolarization activated current $\left(I_{\mathrm{h}}>100\right.$ $\mathrm{pA})$, slow pacemaker-like firing rate $(<5 \mathrm{~Hz})$, and long action potential duration $(>2 \mathrm{~ms})$. Each slice received only a single drug exposure. Drugs were applied in known concentrations to the superfusion medium. Nicotine, EGTA, neostigmine, and atropine were dissolved in distilled water, whereas all the other drugs were dissolved in DMSO. The final concentration of DMSO was $<0.01 \%$. Action potential frequency was analyzed off-line with MiniAnalysis software (Synaptosoft). The averaged action potential frequency within the first minute immediately before drug administration was taken as baseline, and the averaged frequency for the 1 min period centered on the peak response was taken for drug effect.

In vivo. Male Sprague Dawley rats (63-90 d; Harlan) were anesthetized with urethane $(1300 \mathrm{mg} / \mathrm{kg}$, i.p.) and placed in a stereotaxic apparatus (Kopf) with their femoral vein cannulated for intravenous administration of pharmacological agents. Thereafter, the scalp was retracted and one burr hole was drilled above the VTA (AP, $-6.0 \mathrm{~mm}$ from bregma; lateral, $0.3-0.6 \mathrm{~mm}$ from midline) for the placement of a recording electrode. VTA was localized according to the stereotaxic atlas of Paxinos and Watson (1997). Single-unit activity of neurons located in VTA (ventral, $7.0-8.0 \mathrm{~mm}$ from the cortical surface) was recorded extracellularly with glass micropipettes filled with $2 \%$ pontamine sky blue dissolved in $0.5 \mathrm{M}$ sodium acetate (impedance, $2-5 \mathrm{M} \Omega$ ). Single-unit activity was filtered (bandpass, $500-5000 \mathrm{~Hz}$ ), and individual spikes were isolated by means of a window discriminator (Digitimer), displayed on a digital storage oscilloscope (TDS 3012; Tektronics). Experiments were sampled on-line and off-line with Spike2 software (Cambridge Electronic Design) by a computer connected to the CED 1401 interface (Cambridge Electronic Design). Since only one cell was recorded per rat, single units were isolated and identified according to the already published criteria (Melis et al., 2008). VTA dopamine neurons were selected when all criteria for identification were fulfilled: firing rate, $<10 \mathrm{~Hz}$; duration of action potential, $>2.5 \mathrm{~ms}$ as measured from start to end; inhibitory responses to hindpaw pinching (Lecca et al., 2012).

\section{Behavioral study: forced swim test}

Male Sprague Dawley rats (60-90 d; Harlan) were used. All behavioral experiments were conducted between 10:00 A.M. and 3:00 P.M.

The forced swim test was performed in accordance with a previously described procedure (Castagne et al., 2011). As an index of a depressivelike status, the following behavioral parameter was measured: immobility, which is time (seconds) spent by the animal floating in the water performing the minimum amount of movements with the anterior paws, to maintain its head above the water surface.

\section{Biochemical studies}

Western blotting. Male Sprague Dawley rats (63-90 d; Harlan) were administered PNU282987 (PNU; $3 \mathrm{mg} / \mathrm{kg}$, i.p.), MK886 (1 mg/kg, i.p.), WY14643 (WY; $40 \mathrm{mg} / \mathrm{kg}$, i.p.), or vehicle (5 ml/kg, i.p.) $30 \mathrm{~min}$ before decapitation. The VTA was dissected immediately and frozen in liquid nitrogen. Frozen samples of VTA were sonicated in cell lysis buffer (50 mм TRIS, pH 7.4, $250 \mathrm{~mm} \mathrm{NaCl}, 5$ mм EDTA, 50 mм NaF, 1 mм sodium orthovanadate, $1 \%$ Triton $\mathrm{X}-100,0.02 \% \mathrm{NaN}_{3}$ ) containing $1 \mathrm{~mm}$ phenylmethylsulfonyl fluoride and protease inhibitor mixture. Protein concentrations of the lysates were measured by the Bio-Rad DC Protein Assay. $\beta_{2}$ subunit protein was immunoprecipitated from whole-cell lysates using a rabbit polyclonal antibody raised against a recombinant protein corresponding to amino acids $342-433$ of the human $\beta_{2}$ subunit (sc-11372, Santa Cruz Biotechnology). Antibodies were coupled to protein A Dynabeads (Invitrogen) using $5 \mu \mathrm{g}$ of anti- $\beta_{2}$ antibody by rotating the mixture for $10 \mathrm{~min}$ at room temperature. Beads were washed twice in 
PBS, and the antibody-conjugated beads were incubated with $250 \mu \mathrm{g}$ (VTA) of protein lysate for $10 \mathrm{~min}$ at $4^{\circ} \mathrm{C}$, followed by three washing steps in PBS supplemented with $0.1 \%$ Tween 20 (Sigma-Aldrich). Bound protein was eluted with $4 \times \mathrm{XT}$ sample buffer (Bio-Rad) and a reducing agent (Bio-Rad). The immunoprecipitates were separated on an XT Criterion $10 \%$ gel (Bio-Rad) with $1 \times$ XT MOPS running buffer (Bio-Rad) for $1 \mathrm{~h}$ at $175 \mathrm{~V}$ (constant) and subsequently electro-transferred to a nitrocellulose membrane at $400 \mathrm{~mA}$ (constant) for $1 \mathrm{~h}$. The membranes were incubated with 4G10 anti-phosphotyrosine (PY) antibodies (Millipore). Chemiluminescence was detected and quantified with the Versa Doc 1000 Imaging System (Bio-Rad). Samples from control and treated rats were immunoblotted and analyzed together. To control for equal loading, blots incubated with a phospho-tyrosine antibody were reprobed with the nonphosphorylated $\beta 2$ subunit nAChR antibody. Moreover, the amount of phosphorylated receptor was normalized to the amount of total nAchR. Values obtained from treated rats were calculated as percentages of control values.

$\mathrm{N}$-Acylethanolamine quantification. Midbrain slices containing the VTA from Sprague Dawley rats (29-33 d; Harlan) were prepared as described previously (Melis et al., 2006). After recovery, slices underwent different pharmacological treatments and were then frozen. Frozen slices were homogenized and extracted with $50 \mathrm{~mm}$ chloroform/methanol/ Tris-HCl, pH 7.5 (2:1:1, v/v), containing internal deuterated standards for anandamide (AEA), PEA, and OEA quantification by isotope dilution ([2 H]8AEA, [2 $\mathrm{H}] 4$ PEA, [2 H]4 OEA; Cayman Chemical). The lipidcontaining organic phase was dried down, weighed, and prepurified by open-bed chromatography on a silica gel. Fractions were obtained by eluting the column with 90:10 (v/v) chloroform/methanol. AEA, PEA, and OEA were quantified by liquid chromatography-atmospheric pressure chemical ionization-mass spectrometry [1100 HPLC system (Agilent Technologies) equipped with MS Detector 6110 single quadruple] and using selected ion monitoring at $\mathrm{M}+1$ values for the four compounds and their deuterated homologs, as described previously (Di Marzo et al., 2001; Piscitelli et al., 2011).

\section{Immunohistochemistry}

After recordings, slices containing biocytin fills were fixed in $4 \%$ paraformaldehyde in $0.1 \mathrm{M}$ PBS, $\mathrm{pH} 7.4$, for $3 \mathrm{~h}$ and washed three times with PBS, pH 7.4. Preblocking of tissue sections was performed with $10 \%$ normal donkey serum (NDS), $1 \%$ bovine serum albumin (BSA), and $0.2 \%$ Triton $\mathrm{X}-100$ in PBS for $1 \mathrm{~h}$ at room temperature. Sections were then incubated for $24 \mathrm{~h}$ at $4^{\circ} \mathrm{C}$ with a mouse monoclonal anti-TH antibody (1:400; Millipore) in PBS containing 0.2\% Triton X-100, 0.1\% BSA, and $1 \%$ NDS. Then, after being washed in PBS/0.2\% Triton X-100, sections were incubated for $2 \mathrm{~h}$ at room temperature with Alexa Fluor 488labeled donkey anti-mouse IgG (1:500; Invitrogen) and strepdavidin Alexa FluorR 594 (1:1000; Invitrogen) for $2 \mathrm{~h}$ in the dark at room temperature. Sections were then rinsed and mounted on slides using VectaShield antifade mounting media (Vector Laboratories) and visualized using an Olympus IX 61 microscope. Images were taken with a 12-bit cooled F View II camera (Olympus). Color compositions were made using images of single antibodies as RGB channels. After being captured on the computer, images were analyzed using the Cell P AnalySIS software module.

\section{Statistical analysis}

All the numerical data are given as mean \pm SEM. Data were compared and analyzed by using two-way ANOVA for repeated measures (treatment $\times$ time), or one-way ANOVA or Student's $t$ test for repeated measures when appropriate. Post hoc multiple comparisons were made using either the Dunnett's test or the Bonferroni's test. The significance level was established at $p<0.05$.

\section{Drugs}

Nicotine [(-)-nicotine hydrogen tartrate], EGTA (tetrasodium salt), biocytin, neostigmine bromide, and atropine sulfate were purchased from Sigma-Aldrich. MK886, WY14643, PNU282987, GW6471, methyllycaconitine, dihydro- $\beta$-erythroidine hydrobromide, and amitriptyline were purchased from Tocris. URB597 (URB) was purchased from Cayman Chemical. For the in vivo experiments, MK886 was dissolved in
Table 1. Data are means \pm SEM and were compared by two-way ANOVA, followed by the Bonferroni's test

\begin{tabular}{lcccc}
\hline & Control & neo + atro & PNU & PNU+EGTA \\
\hline AEA & $73.2 \pm 9.5$ & $78.9 \pm 8.7$ & $69.5 \pm 8.1$ & $44.6 \pm 5.9$ \\
PEA & $166.5 \pm 13.7$ & $593.1 \pm 34.2^{* * *}$ & $295.5 \pm 37.1^{* *}$ & $166.3 \pm 15.8^{\#}$ \\
OEA & $164.1 \pm 6$ & $739.2 \pm 97.4^{* * *}$ & $265.2 \pm 34.8^{* *}$ & $158.4 \pm 17.1^{\#}$ \\
\hline
\end{tabular}

Data are expressed as picomoles per gram tissue weight. ${ }^{* * *} p<0.0001,{ }^{* *} p<0.001$ versus respective control; $\# p<0.05$ versus PNU.

10\% Tween 80, 20\% DMSO, and 70\% distilled water and administered (5 $\mathrm{ml} / \mathrm{kg}$, i.p.) $1 \mathrm{~h}$ before testing. PNU282987 was dissolved in saline solution and administered ( $5 \mathrm{ml} / \mathrm{kg}$, i.p.) $30 \mathrm{~min}$ before testing. Amitriptyline was dissolved in saline solution and administered $(5 \mathrm{ml} / \mathrm{kg}$, i.p.) $1 \mathrm{~h}$ before testing.

\section{Results}

\section{$\mathrm{N}$-Acylethanolamine formation in the midbrain requires} $\alpha 7-n A C h R-m e d i a t e d \mathrm{Ca}^{2+}$ entry

In cortical neurons, NAE formation depends on enhanced cholinergic tone and increased cytosolic $\mathrm{Ca}^{2+}$ (Stella and Piomelli, 2001). The levels of endogenous PPAR $\alpha$ ligands (i.e., PEA and OEA) were measured in midbrain slices in which endogenous acetylcholine actions at nAChRs were enhanced and isolated by incubating the slices with the acetylcholinesterase inhibitor neostigmine $(2 \mu \mathrm{M}, 5 \mathrm{~min})$ and the muscarinic receptor antagonist atropine ( $5 \mu \mathrm{M}, 5 \mathrm{~min})$. We found that the levels of OEA and PEA were selectively increased [neo+atro: PEA, $593.1 \pm 34.2$ $\mathrm{pmol} / \mathrm{g}$ tissue weight, $p=0.0001, t$ test; OEA, $739.2 \pm 97.4$ $\mathrm{pmol} / \mathrm{g}$ tissue weight, $p=0.0001, t$ test; AEA, $78.9 \pm 8.7 \mathrm{pmol} / \mathrm{g}$ tissue weight, $p=0.2$, $t$ test; $n=5$ for all groups; Table 1, Fig. $1 A]$. Since key synthesizing enzymes for OEA and PEA are $\mathrm{Ca}^{2+} \mathrm{de}-$ pendent (Astarita et al., 2008) and low-affinity $\alpha 7$-nAChRs are $\mathrm{Ca}^{2+}$ permeable (Bertrand et al., 1993), they could participate in NAE formation in the midbrain. To test this hypothesis, NAE levels were measured after activation of $\alpha 7$-nAChRs in midbrain slices. The $\alpha 7$-nAChR agonist PNU282987 (PNU, $50 \mathrm{nM}, 5 \mathrm{~min}$ ) increased levels of OEA (265.2 $\pm 34.8 \mathrm{pmol} / \mathrm{g}$ tissue weight; $p<$ $0.001, t$ test; $n=5$; Table 1, Fig. $1 B)$ and PEA (295.5 \pm 37.1 $\mathrm{pmol} / \mathrm{g}$ tissue weight; $p<0.001, t$ test; $n=5$; Table 1, Fig. $1 B$ ) but not of AEA $(69.5 \pm 8.1 \mathrm{pmol} / \mathrm{g}$ tissue weight; $p=0.3$, $t$ test; $n=$ 5; Table 1, Fig. 1B). The effect of PNU282987 was $\mathrm{Ca}^{2+}$ dependent, as the levels of PEA and OEA were not modified in the presence of the $\mathrm{Ca}^{2+}$ chelator EGTA (5 mM; PNU+EGTA: PEA, $166.3 \pm 15.8 \mathrm{pmol} / \mathrm{g}$ tissue weight, $p<0.01$; OEA, $158.4 \pm 17.1$ $\mathrm{pmol} / \mathrm{g}$ tissue weight, $p<0.05, t$ test; AEA: $44.6 \pm 5.9 \mathrm{pmol} / \mathrm{g}$ tissue weight, $p>0.05 ; F_{(1,16)}=9.27 ; n=5$ for all groups; two-way ANOVA followed by the Bonferroni's test; Table 1, Fig. 1B).

We previously suggested that endogenous PPAR $\alpha$ ligands act as modulators of $\beta 2^{*}$-nAChR function in VTA dopamine cells through a nongenomic mechanism involving activation of tyrosine kinases and phosphatases (Melis et al., 2008, 2010). To study the molecular basis of such an interaction, we analyzed phosphorylation of $\beta 2$ subunits with Western blot analysis after in vivo exposure to the $\alpha 7-\mathrm{nAChR}$ agonist PNU ( $3 \mathrm{mg} / \mathrm{kg}$, i.p.): an increased immunoreactivity of $\beta 2$ subunits phosphorylated on a tyrosine residue in VTA total homogenates was observed in PNU-treated animals (139.1 $\pm 9.8 \% ; n=9$; one-way ANOVA followed by Bonferroni's test; $F_{(2,24)}=8.9 ; p=0.001$; Fig. $1 C$ ). This effect was blocked by pretreatment with the PPAR $\alpha$ antagonist MK886 (1 mg/kg, i.p., $30 \mathrm{~min}$ before PNU treatment; $112.4 \pm 6.1 \% ; n=9$; one-way ANOVA followed by Bonferroni's test; $F_{(2,24)}=8.9 ; p=0.001$; Fig. $\left.1 C\right)$ and mimicked by the syn- 
A

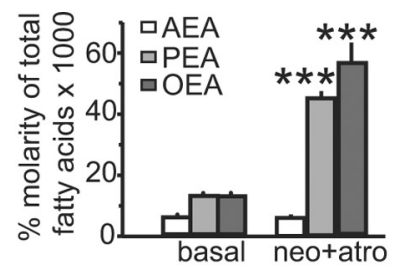

B

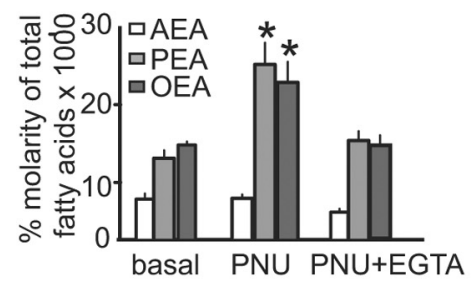

C

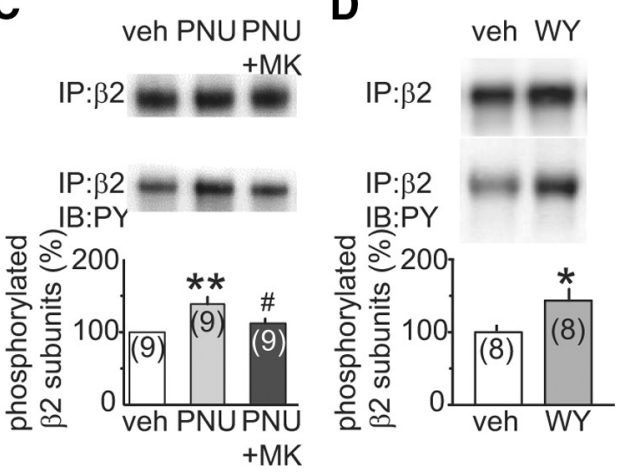

Figure 1. Enhanced cholinergic tone increases levels of endogenous PPAR $\alpha$ agonists. $A$, The levels of endogenous PPAR $\alpha$ ligands (PEA and OEA), but not of the endocannabinoid anandamide (AEA), are increased by enhancing acetylcholine activation of nAChRs (neo + atro: $p=$ 0.0001 for both PEA and OEA, $t$ test; $n=5$ for all groups). $B, \alpha 7$-nAChR activation by PNU enhances PEA ( $p=0.007, t$ test; $n=5)$ and 0EA $(p=0.04, t$ test; $n=5)$ levels in $\mathrm{Ca}^{2+}$. dependent manner (PNU+EGTA: $p=0.01$ and $p=0.02$ for PEA and OEA, respectively; $t$ test). C, Representative immunoblots and summarizing bar graph showing that PNU282987 (3 mg/ $\mathrm{kg}$, i.p.) causes an increase in $\beta 2$ subunit phosphorylation in rat VTA homogenates that is blocked by the PPAR $\alpha$ antagonist MK886 (1 mg/kg, i.p.). D, Representative immunoblots and summarizing bar graph showing that the PPAR $\alpha$ agonist WY ( $40 \mathrm{mg} / \mathrm{kg}$, i.p.) increases $\beta 2$ subunit phosphorylation in rat VTA homogenates. For each experiment in $C$ and $\boldsymbol{D}$, tissue lysates containing the same amount of total proteins were subjected to immunoprecipitation (IP) with anti- $\beta 2$ AChR antibody and were immunoblotted with anti-PY antibody. The IPs were run on the same immunoblots and analyzed together. The blots were stripped and reprobed with anti- $\beta_{2}$ AChR antibody to normalize for protein loading. Band size, $50 \mathrm{kD}$. Numbers in bars indicate $n$ values. Data are expressed as mean \pm SEM. ${ }^{*} p<0.05 ;{ }^{* *} p<0.001$; ${ }^{* * *} p<$ $0.0001 ; \#<0.05 ;$ PNU + MK versus PNU. veh, Vehicle.

thetic PPAR $\alpha$ agonist WY (40 mg/kg, i.p., 15 min before tissue collection; $143.6 \pm 3.7 \% ; n=8 ; t=2.78 ; p=0.01$; Fig. $1 D)$, further substantiating the constitutive interaction between $\operatorname{PPAR} \alpha$ and $\beta 2^{*}$-nAChRs in the VTA.

\section{Enhanced cholinergic drive to $\alpha 7-n A C h R s$ modulates} dopamine neuronal activity through activation of PPAR $\alpha$

We next assessed whether pharmacological manipulations resulting in increased levels of endogenous ligands of PPAR $\alpha$ in midbrain slices would affect VTA dopamine neuronal activity. We performed whole-cell current-clamp recordings from rat dopamine cells in the lateral portion of the VTA under the same experimental conditions (see above). To isolate cholinergic responses, experiments were performed in the presence of CNQX $(10 \mu \mathrm{M}), \mathrm{D}-\mathrm{AP}-5(100 \mu \mathrm{M})$, and picrotoxin $(100 \mu \mathrm{M})$ to block AMPA, NMDA, and $\mathrm{GABA}_{\mathrm{A}}$ receptor-mediated responses, re- spectively. When endogenous acetylcholine actions at nAChRs were enhanced, by applying both the acetylcholinesterase inhibitor neostigmine $(2 \mu \mathrm{M}, 3 \mathrm{~min})$ and the muscarinic antagonist atropine ( $5 \mu \mathrm{M}, 3 \mathrm{~min}$ ), we observed an increased dopamine cell firing rate (neo + atro, $n=5$; Table 2 ) consistent with an endogenous cholinergic tone in the midbrain slice preparation (Melis et al., 2010; Mao et al., 2011). We found that subsequent blockade of $\alpha 7$-nAChRs with methyllycaconitine (MLA), at a concentration that per se had no effect on the dopamine cell firing rate $(3 \mathrm{nM}, 5$ min) (Melis et al., 2010), enhanced dopamine neuronal activity $(+$ MLA: $284.6 \pm 36.9 \%, t=5.2, n=5, p=0.02$, paired $t$ test; Fig. $2 A$, Table 2). These effects are related to elevated ACh levels in the slice, since a lower concentration of neostigmine (200 nM; + atropine, $5 \mu \mathrm{M}, 3 \mathrm{~min}$ ) was unable to enhance the dopamine neuronal firing rate $(93.3 \pm 7 \%, t=1.2, n=8, p=0.34$, paired $t$ test; Table 2). Moreover, increased firing rate after enhanced ACh in the slice and blockade of $\alpha 7$-nAChRs occurred through activation of $\alpha 4 \beta 2$-nAChRs, since the effect was fully blocked in the presence of the $\alpha 4 \beta 2$-nAChR antagonist dihydro- $\beta$-erythroidine $(1 \mu \mathrm{M}, 5 \mathrm{~min}$; $+\mathrm{DH} \beta \mathrm{E}: 82.1 \pm 18.6 \%, t=5.1, n=5, p=0.035$, paired $t$ test; Fig. $2 B$, Table 2). These results suggest that ACh acting at $\alpha 7$-nAChRs exert a negative control on the firing rate of dopamine neurons through $\beta 2^{*}$-nAChRs. Additionally, when the actions of endogenous ligands at PPAR $\alpha$ were blocked by the PPAR $\alpha$ antagonist MK886, at a concentration that had no effect on firing frequency per se (Melis et al., 2008, 2010), VTA dopamine cells underwent an aberrant excitation ( + MK886: $548.1 \pm$ $21.2 \%, F_{(19,80)}=1.78, n=5, p=0.03$, one way ANOVA; MK886+MLA vs MLA: $F_{(1,20)}=4.86, n=5, p=0.05$, two-way ANOVA; Fig. 2C, Table 2). Notably, the effects of hypercholinergic tone occurring through activation of PPAR $\alpha$ do not require activation of muscarinic AChRs (+ neo+MLA vs neo+MLA+MK886: $t=3.4, n=5, p=0.07$; Fig. $2 D$, Table 2).

To test the hypothesis that $\mathrm{Ca}^{2+}$ mediates the effects of $\alpha 7$ nAChRs on firing rate, EGTA ( $5 \mathrm{~mm}, 3 \mathrm{~min}$ ) was perfused. EGTA had no effect on the dopamine cell firing rate per se (Fig. 2E) but augmented dopamine neuron activity once cholinergic tone was elevated (neo+atro+EGTA: $221.1 \pm 16.6 \%, t=8.09, n=6, p=$ 0.007 , paired $t$ test; EGTA: $85 \pm 25.5 \%, t=0.78, n=6, p=0.23$, paired $t$ test; Fig. $2 E$, Table 3$)$. These effects on firing activity further increased in the presence of MLA ( $3 \mathrm{~min} ; 293.2 \pm 33.3 \%$, $t=6.13, n=6, p=0.02$, paired $t$ test; Fig. $2 E$, Table 3 ).

Given that the $\alpha 7$-nAChR agonist PNU282987 increases both the levels of endogenous PPAR $\alpha$ ligands and phosphorylation of $\beta 2$ subunits in the VTA, we next tested whether bath application of PNU282987 (50 nM, $5 \mathrm{~min}$ ) was able to affect the dopamine neuronal firing rate through PPAR $\alpha$. PNU282987 reduced dopamine cell spontaneous activity $(50.4 \pm 5.6 \% ; t=4.88 ; n=5 ; p=$ 0.02 , paired $t$ test; Fig. $3 A, B$, Table 3 ), and this effect was blocked by two structurally different PPAR $\alpha$ antagonists MK886 $\left(113.6 \pm 4.3 \% ; F_{(1,133)}=12.84 ; n=5 ; p=0.009\right.$, two-way ANOVA followed by Bonferroni's test; Fig. $3 A$, Table 3$)$ and GW6471 (100 nM; $118.4 \pm 4.3 \% ; F_{(1,133)}=11.97 ; n=5 ; p=0.01$, two-way ANOVA followed by Bonferroni's test; Fig. $3 A$ ).

NAEs are mainly degraded by the fatty acid amide hydrolase (FAAH) (Ueda et al., 2000) localized in the postsynaptic compartment (Gulyas et al., 2004). We next tested whether pharmacological blockade of FAAH would potentiate $\alpha 7$-nAChRmediated response: dopamine cells were filled with URB597 (100 nM) to rapidly inactivate FAAH, and PNU282987 was then applied ( $50 \mathrm{nM}, 5 \mathrm{~min}$ ). Figure $3 B$ shows that, in the presence of URB597, the effect PNU282987 on dopamine cell firing activity was not enhanced (URB+PNU, $\sim 40 \%$ of basal firing rate; 
Table 2. Summary of the effects of different drugs acting at nAChRs and PPAR $\alpha$ on VTA dopamine neuron's firing rate

\begin{tabular}{|c|c|c|c|c|c|}
\hline & neo $(200 \mathrm{~nm})+$ atro & neo + atro & neo + atro + MLA & neo + atro $+M L A+D H \beta E$ & neo + atro +MLA+MK886 \\
\hline Firing rate ( $\%$ of baseline) & $93.3 \pm 7 \%^{a}$ & $130.1 \pm 9.6 \% *$ & $284.6 \pm 37 \%^{*}$ & $82.1 \pm 18.6 \%{ }^{* *}$ & $548.1 \pm 21 \% * * *$ \\
\hline Effect on firing rate & $=$ & $\uparrow$ & $\uparrow \uparrow$ & $=$ & $\uparrow \uparrow \uparrow$ \\
\hline
\end{tabular}

See text for further details. Drug concentrations are as follows: neo, $2 \mu \mathrm{m}$ unless differently stated; atro, $5 \mu \mathrm{M} ; \mathrm{MLA}, 3 \mathrm{~nm}$; DH $\beta E, 1 \mu \mathrm{M} ; \mathrm{MK} 886,0.3 \mu \mathrm{M}$.

${ }^{a}$ Not significant versus baseline.

${ }^{*} p<0.05$ versus baseline.

${ }^{* *} p<0.05$ versus ne + atro; not significant versus baseline.

${ }^{* * *} p<0.05$ versus neo + atro + MLA; $p<0.05$ versus baseline.

Table 3. Summary of the effects of different drugs acting at nAChRs and PPAR $\alpha$ on VTA dopamine neuron's firing rate

\begin{tabular}{|c|c|c|c|c|c|}
\hline & neo + atro + EGTA & neo + atro +EGTA + MLA & PNU & PNU+MK886 & PNU+URB597 \\
\hline Firing rate (\% of baseline) & $221.1 \pm 17 \%^{*}$ & $293.2 \pm 33 \%^{*}$ & $50.4 \pm 5.6 \%^{* *}$ & $113.6 \pm 4.3 \%^{* * *}$ & $40.4 \pm 17.9 \%^{a}$ \\
\hline Effect on firing rate & $\uparrow \uparrow$ & $\uparrow \uparrow \uparrow$ & $\downarrow$ & $=$ & $\downarrow$ \\
\hline
\end{tabular}

See text for further details. Drug concentrations are as follows: neo, $2 \mu \mathrm{m}$ unless differently stated; atro, $5 \mu \mathrm{m} ; \mathrm{MLA}, 3 \mathrm{~nm} ; \mathrm{MK} 886,0.3 \mu \mathrm{m} ; \mathrm{EGTA}, 5 \mathrm{~mm} ; \mathrm{PNU}, 50 \mathrm{~nm}$; URB597, $0.1 \mu \mathrm{m}$ (intracellular application).

${ }^{a}$ Not significant versus PNU.

${ }^{*} p<0.01$ versus ne + atro

** $p<0.05$ versus baseline.

${ }^{* * *} p<0.01$ versus PNU; not significant versus baseline.

A
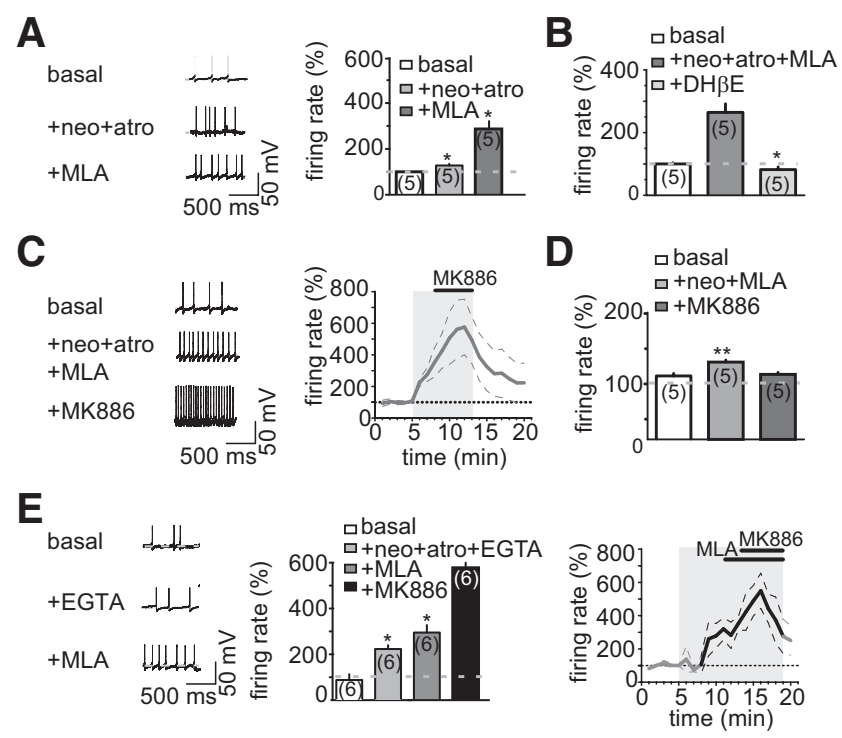

Figure 2. Enhanced cholinergic tone to $\alpha 7$-nAChRs modulates VTA dopamine cell activity via PPAR $\alpha$. A, Ex vivo, the dopamine cell firing rate enhances during increased cholinergic tone at $\beta 2^{*}-n A C h R s$ (neo + atro $+M L A$ ). Left, Current-clamp traces of a dopamine neuron before (basal) and during enhanced cholinergic tone (neo + atro) at $\beta 2^{*}$-nAChRs (neo + atro $+M L A$ ). Right, the effects of enhanced cholinergic tone at $\beta 2^{*}$ $\mathrm{nAChRs}$ on dopamine neurons are represented in a bar graph form. $\boldsymbol{B}$, Bar graph depicting that the effects of increased cholinergic input onto the dopamine cell firing rate depend upon activation of $\beta 22^{*}$-nAChRs because $\mathrm{DH} \beta \mathrm{E}$ fully blocks such effects. $\boldsymbol{C}$, Left, Currentclamp traces of a dopamine neuron before (basal), during enhanced cholinergic tone at $\beta 2^{*}$-nAChRs (neo + atro $+M L A$ ), and once PPAR $\alpha$ are blocked (+MK886). Right, Time course of the effect of neo + atro + MLA alone (shaded area) or together with MK886 (black bar) on dopamine neuron activity. D, The synthesis of endogenous PPAR $\alpha$ ligands after raises in $\mathrm{ACh}$ and their consequent effects on the dopamine firing rate are not mediated by muscarinic receptor activation (neo+MLA). $\boldsymbol{E}$, Removal of extracellular $\mathrm{Ca}^{2+}(\mathrm{EGTA}+$ neo + atro) enhances the dopamine cell firing rate, which is further increased by blockade of $\alpha 7-n A C h R s$ with MLA. Left, Current-clamp traces of a dopamine neuron before (basal) and during enhanced cholinergic tone in the presence of $\mathrm{Ca}^{2+}$ chelator EGTA (+EGTA) and antagonist of $\alpha 7-n A C h R s ~(+M L A)$. In the central panel, the peak effects are represented in a bar graph form. Right, Time course of EGTA (shaded area) alone or in combination with neo + atro (thick black line) and MLA and MK886 is represented. The black bars represent time of MLA and MK886 application. Numbers in bars indicate $n$ values. Data are expressed as mean \pm SEM. ${ }^{*} p<0.05 ;{ }^{* *} p<0.001$.
$F_{(1,133)}=0.95 ; n=5 ; p=0.5$, two-way ANOVA followed by Bonferroni's test vs PNU alone; Fig. 3B, Table 3). Since we used a concentration of URB597 that is able to prevent nicotineinduced excitation of VTA dopamine neurons (data not shown), in agreement with our previous observation (Melis et al., 2008), we can rule out the possibility that URB597 was not effective in blocking FAAH. Alternatively, URB597 ineffectiveness on enhancing PNU-induced effects on dopamine neuronal activity might result from the actions of the diverse FAAH substrates. In particular, AEA exerts stimulating effects on the firing rate of dopamine cells through activation of TRPV1 receptors (Melis et al., 2008), which might counterbalance, thereby masking, the effects produced by increased levels of OEA and PEA via PPAR $\alpha$.

To determine whether the neurons were indeed dopaminergic, we filled neurons with biocytin while recording the spontaneous activity and subsequently processed slices for TH. In agreement with Zhang et al. (2010), we found that the probability of observing a positive immunohistochemical TH signal varied with the length ( $>3 \mathrm{~min}$ ) of whole-cell patch-clamp recordings with a $\mathrm{KCl}$ internal solution, thereby leading to a false negative (Fig. 3Ca). Therefore, the experiments in Figure $3 B$ were performed with a K-gluconate internal solution while targeting the same neuronal population. Under these conditions, we did not observe any loss of $\mathrm{TH}$ signal (Fig. $3 \mathrm{Cb}$ ), in agreement with Margolis et al. (2010). Thus, changes in excitability downstream of $\alpha 7$-nAChRs mediated by activation of PPAR $\alpha$ are indeed observed in VTA dopamine-containing neurons.

\section{$\alpha 7-n A C h R$ activation blocks the stimulating properties of nicotine in vivo through $\operatorname{PPAR} \alpha$ activation}

As shown previously, PPAR $\alpha$ activation blocks nicotine-induced excitation of dopamine cells in vivo (Melis et al., 2008, 2010; Mascia et al., 2011; Panlilio et al., 2012). Given our present findings that $\alpha 7$-nAChR activation increases the levels of endogenous $\operatorname{PPAR} \alpha$ ligands, one would predict that $\alpha 7-\mathrm{nAChR}$ activation would produce a similar effect on nicotine-induced excitation of dopamine neurons in vivo. Indeed, we found that PNU $(0.5 \mathrm{mg} /$ $\mathrm{kg}$, i.v., $4 \mathrm{~min}$ before nicotine) fully prevented nicotine-induced excitation of dopamine neurons $\left(F_{(1,9)}=32.25 ; p=0.003\right.$, twoway ANOVA followed by Bonferroni's test; $n=5$; Fig. $4 A, B$ ). When rats were pretreated with the PPAR $\alpha$ antagonist MK886 
A
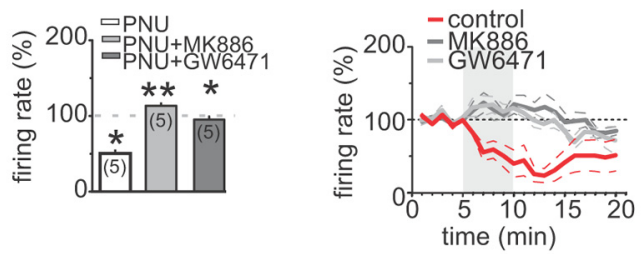

B
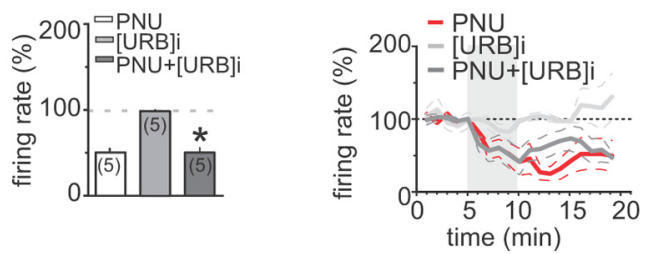

C
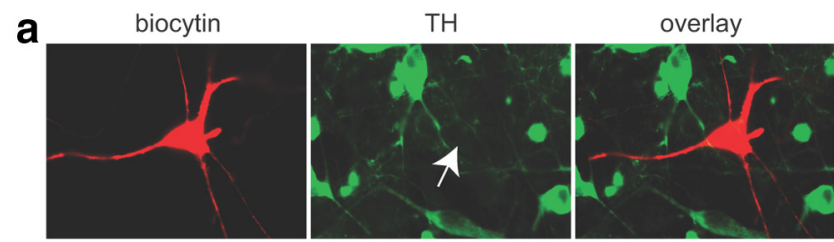

b

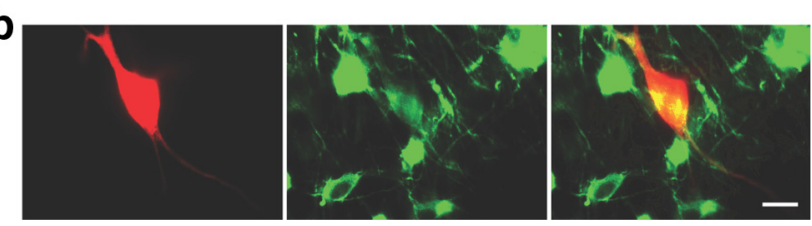

Figure 3. PPAR $\alpha$ activation downstream $\alpha 7$-nAChRs alters excitability of VTA dopamine neurons. A, Left, $\alpha 7$-nAChR agonist PNU reduces dopamine cell activity through synthesis of PPAR $\alpha$ ligands. Right, Time course of the effects of PNU282987 (shaded area) in the absence (thick red line) or presence of the PPAR $\alpha$ antagonists MK886 (thick dark gray line) and GW6471 (thick light gray line). $\boldsymbol{B}$, Left, Effects of $\alpha 7$-nAChR agonist PNU282987 are not enhanced by pharmacological inhibition of FAAH enzyme through application of URB. Right, Time course of the effects of PNU282987 (shaded area) in the absence (thick red line) or presence (thick dark gray line) of FAAH inhibitor URB597 applied through the recording pipette ([URB]i). Numbers in bars indicate $n$ values. Data are expressed as mean \pm SEM. Thick and dashed lines represent means and SEM, respectively. ${ }^{*} p<0.05 ;{ }^{* *} p<0.001$. C, Determination of the dopamine phenotype using immunohistochemistry. $\mathbf{C a}, \mathbf{C b}$, Examples of rat VTA neurons in which relatively long (>20 min) whole-cell recordings were made with a KCl $(\boldsymbol{a})$ and K-gluconate $(\boldsymbol{b})$ internal solution. Post hoc immunocytochemical detection revealed that example neuron $\boldsymbol{a}$ (white arrow indicating presumably a false negative) was $\mathrm{TH}(-)$ and example neuron $\boldsymbol{b}$ was $\mathrm{TH}(+)$. Neurons that were whole-cell patch clamped were backfilled by including biocytin in the recording pipette (red). TH immunohistochemistry routinely labeled the TH-positive neurons (green) when the whole-cell recordings were made with the K-gluconate internal solution. Scale bar, $20 \mu \mathrm{m}$.

( $0.1 \mathrm{mg} / \mathrm{kg}$, i.p., $1 \mathrm{~h}$ before nicotine), which itself had no effect on the dopamine cell firing rate $(3.8 \pm 0.4 \mathrm{~Hz}$ vs vehicle, $3.6 \pm 0.5$ $\mathrm{Hz} ; n=5$ for both groups), PNU282987 was no longer able to prevent nicotine from increasing dopamine neuron frequency $\left(F_{(1,9}=15 ; p=0.004\right.$, two-way ANOVA followed by Bonferroni's test; $n=5$; Fig. $4 A, B)$.

Activation of $\alpha 7-n A C h R s$ has antidepressant-like properties through PPAR $\alpha$ activation

Blockade or desensitization of $\beta 2^{\star}$-nAChRs may exert antidepressant activity in rodent models of depression (Caldarone et al., 2004; Mineur et al., 2011), thus supporting the hypothesis that cholinergic transmission may contribute to the pathophysiology of depression (Janowsky et al., 1972; Mineur and Picciotto, 2010; Philip et al., 2010, 2012). On the other hand, activation of $\alpha 7$-nAChRs displays antidepressant-like properties, thus stirring controversy in terms of whether either acti-
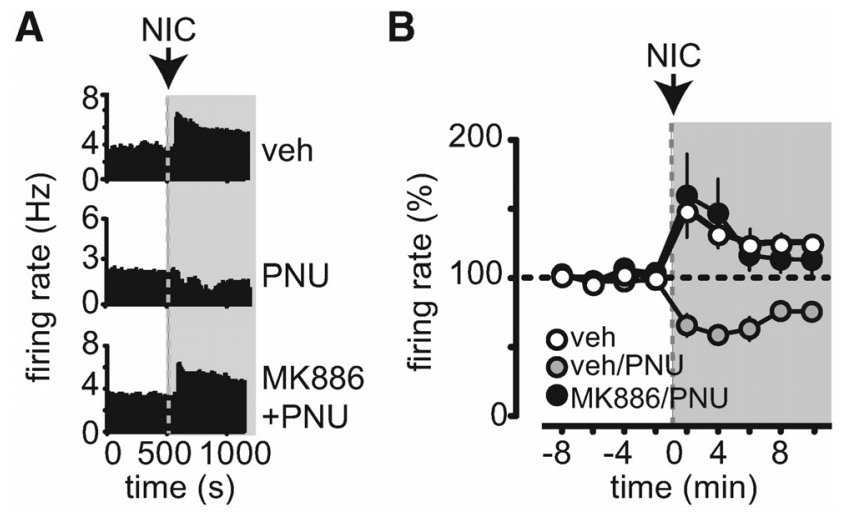

Figure 4. Effects of $\alpha 7-n A C h R$ activation on excitation of VTA dopamine neurons by nicotine. $\boldsymbol{A}$, Representative firing rate histograms showing effects of intravenous nicotine (NIC; injected at arrowhead) on discharge activity of individual VTA dopamine neurons recorded from anesthetized rats. Top, Typical response to $0.2 \mathrm{mg} / \mathrm{kg}$ nicotine in control conditions after intravenous injection of vehicle (veh; 4 min before nicotine). Middle, Lack of effect of $\alpha 7-n A C h R$ agonist PNU (0.5 mg/kg, i.v.; 4 min before nicotine) on spontaneous firing rate of dopamine neurons. Notably, PNU282987 prevents stimulating effects of nicotine. Bottom, The effect of nicotine is restored in a MK886-pretreated animal $(0.1 \mathrm{mg} / \mathrm{kg}$, i.p., $1 \mathrm{~h}$ before beginning of recording session). $\boldsymbol{B}$, Graph illustrating the time course of nicotine effects on firing rate of VTA dopamine neurons. Nicotine-induced excitation of dopamine neurons is abolished by PNU282987 but restored by MK886. Data are expressed as mean \pm SEM. $n=5$ for all groups. Shaded regions beyond dashed lines indicate time after nicotine administration.

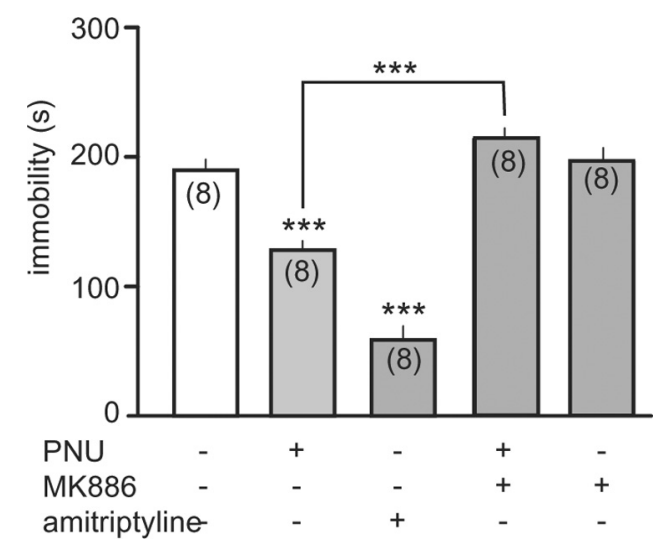

Figure 5. Effects of $\alpha 7-n A C h R$ activation on rat forced swim test require PPAR $\alpha$ activation. The effect of $\alpha 7$-nAChR agonist PNU282987 (3 mg/kg, i.p.) in the forced swim test are PPAR $\alpha$ 32 mediated (*** $p<0.001$, PNU vs corresponding vehicle, veh + MK886, and PNU+MK886 groups; ${ }^{* * *} p<0.001$, amitriptyline group vs all groups). Data are expressed as mean \pm SEM. Numbers in bars indicate $n$ values.

vation or blockade of nAChRs are therapeutically useful in the treatment of depressive disorders (Mineur and Picciotto, 2010; Philip et al., 2010). Remarkably, PEA has also been shown to possess antidepressant-like effects (Yu et al., 2011). Given our present findings linking $\alpha 7$-nAChRs to endogenous $\operatorname{PPAR} \alpha$ ligands and $\beta 2^{\star}$-nAChRs, we tested whether $\alpha 7$ $n A C h R$ activation has antidepressant-like actions through $\operatorname{PPAR} \alpha$ in the rat forced swim test, which is predictive of antidepressant-like activity (Porsolt et al., 1977). PNU-treated $(3 \mathrm{mg} / \mathrm{kg}$, i.p.) rats showed significant reductions in immobility $\left(F_{(4,39)}=46.61 ; p<0.0001\right.$, one-way ANOVA; $n=8$; Fig. $5)$ that were similar to those seen with the currently used antidepressant amitriptyline $(15 \mathrm{mg} / \mathrm{kg}$, i.p.; $n=8)$. Notably, PNU282987-induced reduction of immobility was PPAR $\alpha$ mediated since it was fully blocked by the PPAR $\alpha$ antagonist 


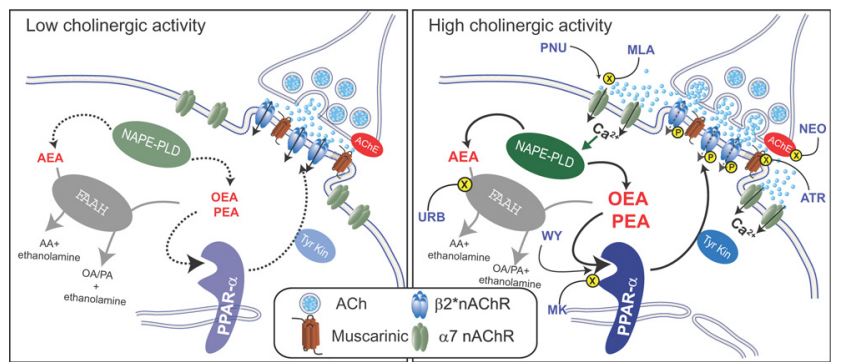

Figure 6. Endogenous PPAR $\alpha$ ligands act as brake during high cholinergic tone on dopamine cells. Schematic diagram illustrating the proposed mechanism of PPAR $\alpha$-induced regulation of cholinergic transmission. Left, During low cholinergic activity, acetylcholine (ACh) preferentially binds to high-affinity $\beta 2^{*} \mathrm{nAChRs}$. Production of endogenous PPAR $\alpha$ ligands, the $\mathrm{N}$-acylethanolamines $\mathrm{AEA}, \mathrm{OEA}$, and PEA, by the $\mathrm{Ca}^{2+}$-sensitive NAPE-PLD remains low and does not trigger PPAR $\alpha$-mediated modulation of $\beta 2^{*}-n A C h R s$. Right, When acetylcholine transmission is potentiated, i.e., by blocking acetylcholinesterase (AChE) with neostigmine (NEO), $\mathrm{Ca}^{2+}$-permeable low-affinity $\alpha 7$-nAChRs are activated. $\alpha 7$-nAChRs are located extrasynaptically on the somatodendritic region of dopamine neurons (Jones and Wonnacott, 2004). $\alpha 7-n A C h R s$ are also activated by the selective agonist PNU and are blocked by MLA. $\alpha 7$-nAChR-mediated increase in intracellular $\mathrm{Ca}^{2+}$ stimulates $\mathrm{N}$-acyl phosphatidylethanolamine phospholipase D (NAPE-PLD), leading to the production of OEA and PEA (and AEA). These molecules, in turn, activate PPAR $\alpha$ that exerts negative modulation of $\beta 2^{*}$-nAChRs operated by a tyrosine kinase-mediated phosphorylation (P). Phosphorylation of $\beta 2^{*} n A C h R s$ might reduce responses to acetylcholine or promote rapid internalization of these receptors. The effects of endogenous PPAR $\alpha$ ligands are mimicked by the synthetic agonist WY and blocked by the PPAR $\alpha$ antagonist MK886 (MK). Increases in levels of $N$-acylethanolmines can also be triggered by blockade of FAAH by URB597. FAAH is the major inactivating enzyme for OEA, PEA and AEA and converts these molecules in ethanolamine and oleic acid $(O A)$, palmitic acid $(P A)$, and arachidonic acid $(A A)$, respectively. However, in this case, AEA might counteract the effects of OEA and PEA by activating TRPV1 (Melis et al., 2008).

MK886 (1 mg/kg, i.p.; $F_{(4,39)}=46.61 ; p<0.0001$, one-way ANOVA; $n=8$; Fig. 5 ).

\section{Discussion}

Our findings reveal a novel form of self-regulation of VTA dopamine cells triggered by low-affinity $\alpha 7-n A C h R$ activation and $\mathrm{Ca}^{2+}$-dependent synthesis of endogenous PPAR $\alpha$ ligands targeted to the same dopamine neurons. PPAR $\alpha$ ligands, as effectors of $\alpha 7$ $n A C h R s$, act as intrinsic modulators of cholinergic transmission and alter dopamine cell excitability, contributing to acetylcholine effects on mood control. This novel form of self-regulation mediated by $\operatorname{PPAR} \alpha$ is selectively activated during increased cholinergic transmission at nAChRs and can be mimicked by $\alpha 7-n A C h R$ activation. Ergo, the attenuated response to acetylcholine during excessive cholinergic drive provides a fine modulation of the mesocorticolimbic dopamine pathway at a single-cell level, where phosphorylation of $\beta 2^{\star}$-nAChRs is the effector mechanism (Fig. 6).

Our observations substantially support a constitutive interaction between PPAR $\alpha$ and $\beta 2^{\star}$-nAChRs in VTA dopamine neurons (Melis et al., 2010), consistent with PPAR $\alpha$ expression within TH-positive neurons (Plaza-Zabala et al., 2010) in the midbrain (Kainu et al., 1994; Cullingford et al., 1998; GalanRodriguez et al., 2009). However, the abundance of constitutive levels of OEA and PEA with respect to AEA is not remarkable, since it results from different incorporation of NAE precursors into phospholipids. In fact, palmitic and oleic acids are mainly esterified in the sn-1 position, whereas arachidonic acid is esterified in position sn-2 of phospholipids. As a result, since NAEs derive from fatty acids in the sn-1 position, OEA and PEA are more abundant than AEA, and the midbrain is no exception to this rule (Melis et al., 2013). What is remarkable is a cell's ability to regulate NAE levels under different conditions, such as exces- sive input drive or metabolic state. Our results show that downstream of $\alpha 7-\mathrm{nAChR}$ activation and subsequent $\mathrm{Ca}^{2+}$ entry, dopamine cells can selectively increase OEA and PEA levels and thereby prevent their own aberrant excitation, a mechanism that was unmasked pharmacologically through blockade of either $\alpha 7$ $n A C h R s$ or PPAR $\alpha$.

Somato-dendritic $\beta 2^{\star}$-nAChRs play a crucial role in controlling the state of activity of VTA dopamine cells (Mameli-Engvall et al., 2006). Dopamine neurons in vivo may exhibit three different types of phasic firing. However, in $\alpha 7$-nAChR knock-out animals, only the most excited state remains. We therefore propose that $\alpha 7$-nAChRs, via $\mathrm{Ca}^{2+}$ influx, OEA and PEA synthesis, and activation of PPAR $\alpha$, act as possible switches in the tonic/ phasic transition regulated by these receptors.

Our study also provides alternative cellular mechanisms elucidating previously reported phenomena, such as the evidence that nicotine patches reduce symptoms of depression in nonsmoking depressed patients (Salín-Pascual et al., 1996). Strangely, both activation of $\alpha 7$-nAChRs and inhibition of $\beta 2^{\star}$ nAChRs contribute to nicotine antidepressant properties (Coe et al., 2005; Mihalak et al., 2006; Mineur and Picciotto, 2010). In fact, desensitization of $\beta 2^{\star}$-nAChRs after chronic nicotine administration is critical for its antidepressant-like properties (Gentry and Lukas, 2002; Shytle et al., 2002; Paradiso and Steinbach, 2003; Mineur and Picciotto, 2009). Accordingly, partial agonists at $\beta 2^{\star}$-nAChRs show robust antidepressant-like properties (Mineur et al., 2011; Philip et al., 2012). In this context, the antidepressant-like properties of PNU282987 (Andreasen and Redrobe, 2009) might be explained by its ability to increase the levels of PEA and OEA, activate PPAR $\alpha$, and phosphorylate $\beta 2^{\star}$ nAChRs. Accordingly, PEA possesses antidepressant-like activity in mice (Yu et al., 2011). Consequently, our findings broaden the already wide variety of PPAR $\alpha$ functions, mainly known to regulate nutrient metabolism and energy homeostasis. Nevertheless, it is worth mentioning that PEA (Normast) is already effective in models of stroke and other CNS traumata (Koch et al., 2011; Schomacher et al., 2012). Thus, as $\alpha 7$-nAChR effectors, PEA and OEA may have a homeostatic role and be the link through which $\alpha 7$-nAChR stimulation proves beneficial in pathological states such as (neuro)inflammation, depressive states, and neurotoxicity. As such, the present study also provides a foundation to explain anorectic, anti-inflammatory, and antidepressant properties of nicotine, as well as of $\alpha 7-\mathrm{nAChR}$ agonists (Avena and Rada, 2012; Bencherif et al., 2011; Lakhan and Kirchgessner, 2011). Activation of PPAR $\alpha$ signaling may prove valuable in disorders or conditions associated with dysfunction of dopamineACh interplay like stress, drug addiction, schizophrenia, and depressive states. Particularly, given that relapse to nicotine is often related to stress and acute withdrawal, where functional upregulated $\beta 2^{\star}$-nAChRs play a key role (Schwartz and Kellar, 1983; Marks et al., 1985), targeting $\operatorname{PPAR} \alpha$ might represent a promising therapeutic approach in nicotine relapse prevention and, ultimately, to help overcome nicotine addiction. Accordingly, synthetic PPAR $\alpha$ agonists not only decrease nicotine taking in experienced animals but also prevent the relapse-inducing effects of reexposure to nicotine, as well as nicotine-associated cues after a period of abstinence (Panlilio et al., 2012). Additionally, given the antidepressant-like activity of FAAH inhibitors (Gobbi et al., 2005; Bortolato et al., 2007; Adamczyk et al., 2008; Umathe et al., 2011), $\operatorname{PPAR} \alpha$ signaling may provide a useful alternative target for novel antidepressant drugs. Finally, activation of either $\operatorname{PPAR} \alpha$ or $\alpha 7$-nAChRs has proven to be effective in preclinical models of schizophrenia (Pichat et al., 2007; Acker et al., 2008; 
Kucinski et al., 2012; Rolland et al., 2012; Thomsen et al., 2010; Zanaletti et al., 2012), thus supporting the involvement of PPAR $\alpha$ and $\alpha 7$-nAChRs in the pathophysiology of this disease (Freedman et al., 2000; Newhouse et al., 2004; Costa et al., 2013).

Whereas targeting PPAR $\alpha$ is promising as a novel therapeutic approach to treat psychiatric disorders such as nicotine addiction and depressive states, $\alpha 7$-nAChR activation might be exploited to overcome current limitations of PEA in clinical use, mainly its poor bioavailability.

\section{References}

Acker BA, Jacobsen EJ, Rogers BN, Wishka DG, Reitz SC, Piotrowski DW, Myers JK, Wolfe ML, Groppi VE, Thornburgh BA, Tinholt PM, Walters RR, Olson BA, Fitzgerald L, Staton BA, Raub TJ, Krause M, Li KS, Hoffmann WE, Hajos $\mathrm{M}$, et al. (2008) Discovery of $N+-[(3 R, 5 R)-1$-azabicyclo[3.2.1] oct-3yl] furo[2,3-c]pyridine-5-carboxamide as an agonist of the alpha7 nicotinic acetylcholine receptor: in vitro and in vivo activity. Bioorg Med Chem Lett 18:3611-3615. CrossRef Medline

Adamczyk P, Golda A, McCreary AC, Filip M, Przegalinski E (2008) Activation of endocannabinoid transmission induces antidepressant-like effects in rats. J Physiol Pharmacol 59:217-228. Medline

Albanese A, Minciacchi D (1983) Organization of the ascending projections from the ventral tegmental area: a multiple fluorescent retrograde tracer study in the rat. J Comp Neurol 216:406-420. CrossRef Medline

Andreasen JT, Redrobe JP (2009) Antidepressant-like effects of nicotine and mecamylamine in the mouse forced swim and tail suspension tests: role of strain, test and sex. Behav Pharmacol 20:286-295. CrossRef Medline

Astarita G, Ahmed F, Piomelli D (2008) Identification of biosynthetic precursors for the endocannabinoid anandamide in the rat brain. J Lipid Res 49:48-57. CrossRef Medline

Avena NM, Rada PV (2012) Cholinergic modulation of food and drug satiety and withdrawal. Physiol Behav 106:332-336. CrossRef Medline

Bencherif M, Lippiello PM, Lucas R, Marrero MB (2011) Alpha7 nicotinic receptors as novel therapeutic targets for inflammation-based diseases. Cell Mol Life Sci 68:931-949. CrossRef Medline

Bertrand D, Galzi JL, Devillers-Thiéry A, Bertrand S, Changeux JP (1993) Mutations at two distinct sites within the channel domain M2 alter calcium permeability of neuronal alpha 7 nicotinic receptor. Proc Natl Acad Sci U S A 90:6971-6975. CrossRef Medline

Bortolato M, Mangieri RA, Fu J, Kim JH, Arguello O, Duranti A, Tontini A, Mor M, Tarzia G, Piomelli D (2007) Antidepressant-like activity of the fatty acid amide hydrolase inhibitor URB597 in a rat model of chronic mild stress. Biol Psychiatry 62:1103-1110. CrossRef Medline

Caldarone BJ, Harrist A, Cleary MA, Beech RD, King SL, Picciotto MR (2004) High-affinity nicotinic acetylcholine receptors are required for antidepressant effects of amitriptyline on behavior and hippocampal cell proliferation. Biol Psychiatry 56:657-664. CrossRef Medline

Castagne V, Moser P, Roux S, Porsolt RD (2011) Rodent models of depression: forced swim and tail suspension behavioral despair tests in rats and mice. Curr Protoc Neurosci Chapter 8:Unit 8.10A. CrossRef Medline

Clarke PB, Schwartz RD, Paul SM, Pert CB, Pert A (1985) Nicotinic binding in rat brain: autoradiographic comparison of [ $3 \mathrm{H}]$ acetylcholine, $[3 \mathrm{H}] \mathrm{ni}-$ cotine, and [125I]-alpha-bungarotoxin. J Neurosci 5:1307-1315. Medline

Coe JW, Brooks PR, Vetelino MG, Wirtz MC, Arnold EP, Huang J, Sands SB, Davis TI, Lebel LA, Fox CB, Shrikhande A, Heym JH, Schaeffer E, Rollema H, Lu Y, Mansbach RS, Chambers LK, Rovetti CC, Schulz DW, Tingley FD 3rd, et al. (2005) Varenicline: an alpha4beta2 nicotinic receptor partial agonist for smoking cessation. J Med Chem 48:3474-3477. CrossRef Medline

Costa M, Squassina A, Congiu D, Chillotti C, Niola P, Galderisi S, Pistis M, Del Zompo M (2013) Investigation of endocannabinoid system genes suggests association between peroxisome proliferator activator receptoralpha gene (PPARA) and schizophrenia. Eur Neuropsychopharmacol, in press. Medline

Cullingford TE, Bhakoo K, Peuchen S, Dolphin CT, Patel R, Clark JB (1998) Distribution of mRNAs encoding the peroxisome proliferator-activated receptor alpha, beta, and gamma and the retinoid X receptor alpha, beta, and gamma in rat central nervous system. J Neurochem 70:1366-1375. CrossRef Medline

Di Marzo V, Melck D, Orlando P, Bisogno T, Zagoory O, Bifulco M, Vogel Z, De Petrocellis L (2001) Palmitoylethanolamide inhibits the expression of fatty acid amide hydrolase and enhances the anti-proliferative effect of anandamide in human breast cancer cells. Biochem J 358:249-255. CrossRef Medline

Freedman R, Adams CE, Leonard S (2000) The alpha7-nicotinic acetylcholine receptor and the pathology of hippocampal interneurons in schizophrenia. J Chem Neuroanat 20:299-306. CrossRef Medline

Fu J, Gaetani S, Oveisi F, Lo Verme J, Serrano A, Rodríguez De Fonseca F, Rosengarth A, Luecke H, Di Giacomo B, Tarzia G, Piomelli D (2003) Oleylethanolamide regulates feeding and body weight through activation of the nuclear receptor PPAR-alpha. Nature 425:90-93. CrossRef Medline

Galan-Rodriguez B, Suarez J, Gonzalez-Aparicio R, Bermudez-Silva FJ, Maldonado R, Robledo P, Rodriguez de Fonseca F, Fernandez-Espejo E (2009) Oleoylethanolamide exerts partial and dose-dependent neuroprotection of substantia nigra dopamine neurons. Neuropharmacology 56:653-664. CrossRef Medline

Gentry CL, Lukas RJ (2002) Regulation of nicotinic acetylcholine receptor numbers and function by chronic nicotine exposure. Curr Drug Targets CNS Neurol Disord 1:359-385. CrossRef Medline

Gobbi G, Bambico FR, Mangieri R, Bortolato M, Campolongo P, Solinas M, Cassano T, Morgese MG, Debonnel G, Duranti A, Tontini A, Tarzia G, Mor M, Trezza V, Goldberg SR, Cuomo V, Piomelli D (2005) Antidepressantlike activity and modulation of brain monoaminergic transmission by blockade of anandamide hydrolysis. Proc Natl Acad Sci U S A 102:18620-18625. CrossRef Medline

Gulyas AI, Cravatt BF, Bracey MH, Dinh TP, Piomelli D, Boscia F, Freund TF (2004) Segregation of two endocannabinoid-hydrolyzing enzymes into pre- and postsynaptic compartments in the rat hippocampus, cerebellum and amygdala. Eur J Neurosci 20:441-458. CrossRef Medline

Janowsky DS, el-Yousef MK, Davis JM, Sekerke HJ (1972) A cholinergicadrenergic hypothesis of mania and depression. Lancet 2:632-635. Medline

Jones IW, Wonnacott S (2004) Precise localization of alpha7 nicotinic acetylcholine receptors on glutamatergic axon terminals in the rat ventral tegmental area. J Neurosci 24:11244-11252. CrossRef Medline

Kainu T, Wikström AC, Gustafsson JA, Pelto-Huikko M (1994) Localization of the peroxisome proliferator-activated receptor in the brain. Neuroreport 5:2481-2485. CrossRef Medline

Klink R, de Kerchove d'Exaerde A, Zoli M, Changeux JP (2001) Molecular and physiological diversity of nicotinic acetylcholine receptors in the midbrain dopaminergic nuclei. J Neurosci 21:1452-1463. Medline

Koch M, Kreutz S, Böttger C, Benz A, Maronde E, Ghadban C, Korf HW, Dehghani F (2011) Palmitoylethanolamide protects dentate gyrus granule cells via peroxisome proliferator-activated receptor-alpha. Neurotox Res 19:330-340. CrossRef Medline

Kucinski A, Syposs C, Wersinger S, Bencherif M, Stachowiak MK, Stachowiak EK (2012) alpha7 neuronal nicotinic receptor agonist (TC-7020) reverses increased striatal dopamine release during acoustic PPI testing in a transgenic mouse model of schizophrenia. Schizophr Res 136:82-87. CrossRef Medline

Lakhan SE, Kirchgessner A (2011) Anti-inflammatory effects of nicotine in obesity and ulcerative colitis. J Transl Med 9:129. CrossRef Medline

Lapish CC, Kroener S, Durstewitz D, Lavin A, Seamans JK (2007) The ability of the mesocortical dopamine system to operate in distinct temporal modes. Psychopharmacology (Berl) 191:609-625. CrossRef Medline

Lecca S, Melis M, Luchicchi A, Muntoni AL, Pistis M (2012) Inhibitory inputs from rostromedial tegmental neurons regulate spontaneous activity of midbrain dopamine cells and their responses to drugs of abuse. Neuropsychopharmacology 37:1164-1176. CrossRef Medline

Lodge DJ, Grace AA (2006) The laterodorsal tegmentum is essential for burst firing of ventral tegmental area dopamine neurons. Proc Natl Acad Sci U S A 103:5167-5172. CrossRef Medline

Lo Verme J, Fu J, Astarita G, La Rana G, Russo R, Calignano A, Piomelli D (2005) The nuclear receptor peroxisome proliferator-activated receptoralpha mediates the anti-inflammatory actions of palmitoylethanolamide. Mol Pharmacol 67:15-19. CrossRef Medline

Mameli-Engvall M, Evrard A, Pons S, Maskos U, Svensson TH, Changeux JP, Faure P (2006) Hierarchical control of dopamine neuron-firing patterns by nicotinic receptors. Neuron 50:911-921. CrossRef Medline

Mao D, Gallagher K, McGehee DS (2011) Nicotine potentiation of excitatory inputs to ventral tegmental area dopamine neurons. J Neurosci 31:6710-6720. CrossRef Medline 
Margolis EB, Coker AR, Driscoll JR, Lemaître AI, Fields HL (2010) Reliability in the identification of midbrain dopamine neurons. PLoS One 5:e15222. CrossRef Medline

Mark GP, Shabani S, Dobbs LK, Hansen ST (2011) Cholinergic modulation of mesolimbic dopamine function and reward. Physiol Behav 104:76-81. CrossRef Medline

Marks MJ, Stitzel JA, Collins AC (1985) Time course study of the effects of chronic nicotine infusion on drug response and brain receptors. J Pharmacol Exp Ther 235:619-628. Medline

Mascia P, Pistis M, Justinova Z, Panlilio LV, Luchicchi A, Lecca S, Scherma M, Fratta W, Fadda P, Barnes C, Redhi GH, Yasar S, Le Foll B, Tanda G, Piomelli D, Goldberg SR (2011) Blockade of nicotine reward and reinstatement by activation of alpha-type peroxisome proliferator-activated receptors. Biol Psychiatry 69:633-641. CrossRef Medline

Melis M, Pillolla G, Bisogno T, Minassi A, Petrosino S, Perra S, Muntoni AL, Lutz B, Gessa GL, Marsicano G, Di Marzo V, Pistis M (2006) Protective activation of the endocannabinoid system during ischemia in dopamine neurons. Neurobiol Dis 24:15-27. CrossRef Medline

Melis M, Enrico P, Peana AT, Diana M (2007) Acetaldehyde mediates alcohol activation of the mesolimbic dopamine system. Eur J Neurosci 26:2824-2833. CrossRef Medline

Melis M, Pillolla G, Luchicchi A, Muntoni AL, Yasar S, Goldberg SR, Pistis M (2008) Endogenous fatty acid ethanolamides suppress nicotine-induced activation of mesolimbic dopamine neurons through nuclear receptors. J Neurosci 28:13985-13994. CrossRef Medline

Melis M, Carta S, Fattore L, Tolu S, Yasar S, Goldberg SR, Fratta W, Maskos U, Pistis M (2010) Peroxisome proliferator-activated receptors-alpha modulate dopamine cell activity through nicotinic receptors. Biol Psychiatry 68:256-264. CrossRef Medline

Melis M, Carta G, Pistis M, Banni S (2013) Physiological role of peroxisome proliferator-activated receptors type alpha on dopamine systems. CNS Neurol Disord Drug Targets 12:70-77. Medline

Mihalak KB, Carroll FI, Luetje CW (2006) Varenicline is a partial agonist at alpha4beta2 and a full agonist at alpha7 neuronal nicotinic receptors. Mol Pharmacol 70:801-805. CrossRef Medline

Mineur YS, Picciotto MR (2009) Biological basis for the co-morbidity between smoking and mood disorders. J Dual Diagn 5:122-130. CrossRef Medline

Mineur YS, Picciotto MR (2010) Nicotine receptors and depression: revisiting and revising the cholinergic hypothesis. Trends Pharmacol Sci 31: 580-586. CrossRef Medline

Mineur YS, Einstein EB, Seymour PA, Coe JW, O’neill BT, Rollema H, Picciotto MR (2011) Alpha4beta2 nicotinic acetylcholine receptor partial agonists with low intrinsic efficacy have antidepressant-like properties. Behav Pharmacol 22:291-299. CrossRef Medline

Newhouse P, Singh A, Potter A (2004) Nicotine and nicotinic receptor involvement in neuropsychiatric disorders. Curr Top Med Chem 4:267-282. CrossRef Medline

Panlilio LV, Justinova Z, Mascia P, Pistis M, Luchicchi A, Lecca S, Barnes C, Redhi GH, Adair J, Heishman SJ, Yasar S, Aliczki M, Haller J, Goldberg SR (2012) Novel use of a lipid-lowering fibrate medication to prevent nicotine reward and relapse: preclinical findings. Neuropsychopharmacology 37:1838-1847. CrossRef Medline

Paradiso KG, Steinbach JH (2003) Nicotine is highly effective at producing desensitization of rat alpha4beta2 neuronal nicotinic receptors. J Physiol 553:857-871. CrossRef Medline

Paxinos G, Watson C (1997) The rat brain in stereotaxic coordinates. San Diego: Academic.

Philip NS, Carpenter LL, Tyrka AR, Price LH (2010) Nicotinic acetylcholine receptors and depression: a review of the preclinical and clinical literature. Psychopharmacology (Berl) 212:1-12. CrossRef Medline

Philip NS, Carpenter LL, Tyrka AR, Price LH (2012) The nicotinic acetylcholine receptor as a target for antidepressant drug development. Sci World J 2012:104105. CrossRef Medline

Picciotto MR, Zoli M, Rimondini R, Léna C, Marubio LM, Pich EM, Fuxe K, Changeux JP (1998) Acetylcholine receptors containing the beta2 subunit are involved in the reinforcing properties of nicotine. Nature 391:173-177. CrossRef Medline

Pichat P, Bergis OE, Terranova JP, Urani A, Duarte C, Santucci V, Gueudet C, Voltz C, Steinberg R, Stemmelin J, Oury-Donat F, Avenet P, Griebel G, Scatton B (2007) SSR180711, a novel selective alpha7 nicotinic receptor partial agonist: (II) efficacy in experimental models predictive of activity against cognitive symptoms of schizophrenia. Neuropsychopharmacology 32:17-34. CrossRef Medline

Piscitelli F, Carta G, Bisogno T, Murru E, Cordeddu L, Berge K, Tandy S, Cohn JS, Griinari M, Banni S, Di Marzo V (2011) Effect of dietary krill oil supplementation on the endocannabinoidome of metabolically relevant tissues from high-fat-fed mice. Nutr Metab (Lond) 8:51. CrossRef Medline

Pistis M, Melis M (2010) From surface to nuclear receptors: the endocannabinoid family extends its assets. Curr Med Chem 17:1450-1467. CrossRef Medline

Plaza-Zabala A, Berrendero F, Suarez J, Bermudez-Silva FJ, Fernandez-Espejo E, Serrano A, Pavon FJ, Parsons LH, De Fonseca FR, Maldonado R, Robledo P (2010) Effects of the endogenous PPAR-alpha agonist, oleoylethanolamide on MDMA-induced cognitive deficits in mice. Synapse 64: 379-389. CrossRef Medline

Porsolt RD, Le Pichon M, Jalfre M (1977) Depression: a new animal model sensitive to antidepressant treatments. Nature 266:730-732. CrossRef Medline

Rodríguez de Fonseca F, Navarro M, Gómez R, Escuredo L, Nava F, Fu J, Murillo-Rodríguez E, Giuffrida A, LoVerme J, Gaetani S, Kathuria S, Gall C, Piomelli D (2001) An anorexic lipid mediator regulated by feeding. Nature 414:209-212. CrossRef Medline

Rolland B, Marche K, Cottencin O, Bordet R (2012) The PPARalpha agonist fenofibrate reduces prepulse inhibition disruption in a neurodevelopmental model of schizophrenia. Schizophr Res Treatment 2012:839853. CrossRef Medline

Salín-Pascual RJ, Rosas M, Jimenez-Genchi A, Rivera-Meza BL, DelgadoParra V (1996) Antidepressant effect of transdermal nicotine patches in nonsmoking patients with major depression. J Clin Psychiatry 57: 387-389. Medline

Schilström B, Rawal N, Mameli-Engvall M, Nomikos GG, Svensson TH (2003) Dual effects of nicotine on dopamine neurons mediated by different nicotinic receptor subtypes. Int J Neuropsychopharmacol 6:1-11. CrossRef Medline

Schomacher J, Farina D, Lindstroem R, Falla D (2012) Chronic traumainduced neck pain impairs the neural control of the deep semispinalis cervicis muscle. Clin Neurophysiol 123:1403-1408. CrossRef Medline

Schwartz RD, Kellar KJ (1983) Nicotinic cholinergic receptor binding sites in the brain: regulation in vivo. Science 220:214-216. CrossRef Medline

Séguéla P, Wadiche J, Dineley-Miller K, Dani JA, Patrick JW (1993) Molecular cloning, functional properties, and distribution of rat brain alpha 7: a nicotinic cation channel highly permeable to calcium. J Neurosci 13:596-604. Medline

Shytle RD, Silver AA, Sheehan KH, Sheehan DV, Sanberg PR (2002) Neuronal nicotinic receptor inhibition for treating mood disorders: preliminary controlled evidence with mecamylamine. Depress Anxiety 16:89-92. CrossRef Medline

Stella N, Piomelli D (2001) Receptor-dependent formation of endogenous cannabinoids in cortical neurons. Eur J Pharmacol 425:189-196. CrossRef Medline

Thomsen MS, Hansen HH, Timmerman DB, Mikkelsen JD (2010) Cognitive improvement by activation of alpha7 nicotinic acetylcholine receptors: from animal models to human pathophysiology. Curr Pharm Des 16:323-343. CrossRef Medline

Ueda N, Puffenbarger RA, Yamamoto S, Deutsch DG (2000) The fatty acid amide hydrolase (FAAH). Chem Phys Lipids 108:107-121. CrossRef Medline

Umathe SN, Manna SS, Jain NS (2011) Involvement of endocannabinoids in antidepressant and anti-compulsive effect of fluoxetine in mice. Behav Brain Res 223:125-134. CrossRef Medline

Wang DV, Tsien JZ (2011) Convergent processing of both positive and negative motivational signals by the VTA dopamine neuronal populations. PLoS One 6:e17047. CrossRef Medline

Wightman RM, Robinson DL (2002) Transient changes in mesolimbic dopamine and their association with "reward." J Neurochem 82:721-735. CrossRef

Wooltorton JR, Pidoplichko VI, Broide RS, Dani JA (2003) Differential desensitization and distribution of nicotinic acetylcholine receptor subtypes in midbrain dopamine areas. J Neurosci 23:3176-3185. Medline

Yang K, Hu J, Lucero L, Liu Q, Zheng C, Zhen X, Jin G, Lukas RJ, Wu J (2009) Distinctive nicotinic acetylcholine receptor functional phenotypes of rat 
ventral tegmental area dopaminergic neurons. J Physiol 587:345-361. CrossRef Medline

Yu HL, Deng XQ, Li YJ, Li YC, Quan ZS, Sun XY (2011) N-palmitoylethanolamide, an endocannabinoid, exhibits antidepressant effects in the forced swim test and the tail suspension test in mice. Pharmacol Rep 63:834-839. Medline

Zanaletti R, Bettinetti L, Castaldo C, Cocconcelli G, Comery T, Dunlop J, Gaviraghi G, Ghiron C, Haydar SN, Jow F, Maccari L, Micco I, Nencini A, Scali C, Turlizzi E, Valacchi M (2012) Discovery of a novel alpha-7 nic- otinic acetylcholine receptor agonist series and characterization of the potent, selective, and orally efficacious agonist 5 -(4-acetyl[ $[1,4]$ diazepan1-yl)pentanoic acid [5-(4-methoxyphenyl)-1H-pyrazol-3-yl] amide (SEN15924, WAY-361789). J Med Chem 55:4806-4823. CrossRef Medline

Zhang TA, Placzek AN, Dani JA (2010) In vitro identification and electrophysiological characterization of dopamine neurons in the ventral tegmental area. Neuropharmacology 59:431-436. CrossRef Medline 